\title{
EFFECTS OF DIFFERENT EDIBLE COATINGS IN PHYSICAL, CHEMICAL AND MICROBIOLOGICAL CHARACTERISTICS OF MINIMALLY PROCESSED PEACHES (PRUNUS PERSICA L. BATSCH)
}

\author{
SANDRIANE PIZATO',3, WILLIAM RENZO CORTEZ-VEGA ${ }^{1}$, JULIANA TAIS ANDREGHETTO de SOUZA', \\ CARLOS PRENTICE-HERNÁNDEZ ${ }^{1}$ and CAROLINE DELLINGHAUSEN BORGES ${ }^{2}$ \\ 'Laboratory of Food Technology, School of Chemistry and Foods, Federal University of Rio Grande, PO Box 474, 96201-900 Rio Grande, RS, Brazil \\ ${ }^{2}$ Department of Food Science, Federal University of Pelotas, Pelotas, RS, Brazil
}

${ }^{3}$ Corresponding author.

TEL: +55 (53) 3233-8621;

FAX: $+55(53) 3233-8745$

EMAIL: sandrianepizato@yahoo.com.br

Received for Publication August 29, 2012 Accepted for Publication November 29, 2012

doi: $10.1111 /$ ffs. 12020

\begin{abstract}
The present work aimed at evaluating the effects of tara gum, xanthan and sodium alginate as edible coatings in physical, chemical and microbiological characteristics of minimally processed peaches. Peaches from Granada cultivar were peeled, cut into cubes and immersed in the solutions with the respective treatment. Four treatments were used. The minimally processed peaches were packed in PET packaging and stored at $4 \pm 1 \mathrm{C}$ for 12 days. Physical and physicochemical analyses were performed, including mass loss, firmness $(\mathrm{N})$, color $\left(L^{*}, a^{*}, b^{*}\right.$ and Hue angle), $\mathrm{pH}$, soluble solids ( ${ }^{\circ}$ Brix), and microbiological evaluations of psychotrophic microorganisms and mold and yeast. The treatment with tara gum associated to citric and ascorbic acids and sodium chloride presented the best results. Tara gum allowed a reduction of mass loss, firmness maintenance, lower color alteration and lower growth of molds and yeasts. Therefore, this gum presents potential for application as edible coating.
\end{abstract}

\section{PRACTICAL APPLICATIONS}

Fresh-cut peaches are appreciated worldwide for their exotic flavor and nutritional composition. However, their shelf life is limited by changes in color, texture, appearance and microbial growth. An alternative to try to minimize the losses and increase the shelf life of this product is the use of edible coatings, maintaining the quality parameters of fresh fruit. Tara gum is a cheap gum that has not been used as coating on minimally processed fruit, and in this work, this gum showed significant results in the quality of fresh-cut peaches for a longer time. It can be considered useful to the minimal processing industry and used as an alternative to fast food and other ready-to-eat products, attending the demand for healthy and convenient foodstuffs.

\section{INTRODUCTION}

Peach (Prunus persica L. Batsch) is a climacteric fruit originating from Asia. It presents expressive commercial production worldwide mainly in regions of temperate climate (Scorza 2005). Brazil is the 15th largest world producer, despite its favorable geographic position and its edaphic climatic conditions. Among the producer states, Rio Grande do Sul stands out. It is responsible for around 65\% of national production (Sebrae 2012). Peach peculiarities of flavor and aroma result from a balance of sugars, organic acids, phenolic compounds, carotenoids and volatile compounds, making it an appreciated fruit of great commercial importance (Gil et al. 2002; Versari et al. 2002).

Minimally processed fruits offer a convenient and practical product to the consumer, with quality and freshness 
similar to the in natura product. According to Della Cruz (2004), this kind of product provides higher yield, good quality, reduces accidents in kitchens and requires less refrigerated space. Besides the advantages of convenience and quality offered by minimally processed fruits, the possibility of processing them in the producing regions provides a new option to the producers as it adds value to products and is suitable for micro and small family business.

An alternative to reduce the effects caused by the minimal process is the use of edible coatings. They form a thin layer of edible material on the product surface. They are used to inhibit the migration of moisture, oxygen, carbon dioxide, aroma and lipids; introducing additives such as antioxidants and antimicrobials, thereby improving the characteristics, mechanical integrity and handling of food products (Krochta and Mulder-Johnston 1997). However, edible coatings have not been used in the preservation of minimally processed peaches, only in the preservation of the whole fruit as in studies carried out by Oliveira and Cereda (2003), Togrul and Arslan (2004) and Maftoonazad et al. (2008).

Tara gum is extracted from Caesalpinia spinosa endosperm seeds. It is a galactomannan, a neutral polysaccharide used as a thickening agent in foods and, unlike the alginates and gelan gum, it does not form gel on its own (Sittikijyothin et al.2005). Caesalpinia spinosa is native from Bolivia, Peru and Northern Chile; but it is also found in Ecuador, Colombia Venezuela and Cuba. It is believed that Peru is the largest tara gum exporter. Tara gum presents a low relative cost, offering a great economic incentive to its industrial exploitation (Fsanz 2006). So far, it has not been evaluated as edible coating of minimally processed food.

Xanthan gum is a polysaccharide synthesized by a phytopathogenic bacterium from Xanthomonas species (Sutherland 1993). Xanthan gum is used in foods as thickener and stabilizer; however, it does not form gel on its own, only in synergism with galactomannans (García-Ochoa et al. 2000).

Alginates are polysaccharides most commonly used in edible coatings. Sodium alginate is a polysaccharide of natural origin derived mainly from brown seaweed (Çaykara et al. 2005).

Therefore, the aim of the present study was to evaluate the effects of tara gum, xanthan gum and sodium alginate as edible coatings on the microbiological, physical and physicochemical characteristics of minimally processed peaches.

\section{MATERIALS AND METHODS}

\section{Material}

Peaches ( $P$. pérsica L. Batsch) from Granada cultivar were bought from grocery stores in Rio Grande City, with maturity level between $50 \%$ and $70 \%$. The fruits were selected as per size, color and the absence of physiological defects. They were transported in thermo boxes to the Laboratory of Food Technology of the School of Chemistry and Food of Federal University of Rio Grande, where the minimal processing was carried out.

\section{Preparation of Minimally Processed Peaches}

The processing was carried out at approximately 10C, with the utensils previously cleaned in a solution of organic chlorine (dichloroisocyanurate) at a concentration of $2 \mathrm{~g} / \mathrm{l}$. Peaches were selected, washed and sanitized in organic chlorine solution at a concentration of $2 \mathrm{~g} / \mathrm{l}$ for $15 \mathrm{~min}$, peeled and manually cut into cubes of approximately $2.5 \times 2.5 \mathrm{~cm}$ using stainless steel knives. Then the pieces were rinsed with chlorinated water $(0.2 \mathrm{~g} / \mathrm{l})$ to eliminate the cell juice spilled.

\section{Preparation and Coating Application}

Xanthan gum (Shandong Fufeng), tara gum (Silva Extract Srl) and sodium alginate (Kimica) were slowly dissolved in water under constant agitation for about $1 \mathrm{~h}$. Then xanthan gum was heated at 60C for $20 \mathrm{~min}$ (Xuewu et al. 1996), tara gum at $80 \mathrm{C}$ for $30 \mathrm{~min}$ (Sittikijyothin et al. 2007) and sodium alginate at $70 \mathrm{C}$ for $30 \mathrm{~min}$, then cooled at $15 \mathrm{C}$ (Rojas-Graü etal. 2007). After cooling the solutions, calcium chloride, citric and ascorbic acids and glycerol were added under agitation.

The coatings were prepared in aqueous solution: treatment 1 - control (cut peach); treatment 2 - alginate $(2 \%$ $\mathrm{w} / \mathrm{v})$, ascorbic acid $(1 \% \mathrm{w} / \mathrm{v})$, citric acid $(0.25 \% \mathrm{w} / \mathrm{v}), \mathrm{CaCl}_{2}$ $(1 \% \mathrm{w} / \mathrm{v})$ and glycerol $(1 \% \mathrm{v} / \mathrm{v})$; treatment $3-$ xanthan gum $(0.5 \% \mathrm{w} / \mathrm{v})$, ascorbic acid $(1 \% \mathrm{w} / \mathrm{v})$, citric acid $(0.25 \% \mathrm{w} / \mathrm{v})$, $\mathrm{CaCl}_{2}(1 \% \mathrm{w} / \mathrm{v})$ and glycerol $(1 \% \mathrm{v} / \mathrm{v})$; treatment $4-$ tara gum $(0.5 \% \mathrm{w} / \mathrm{v})$, ascorbic acid $(1 \% \mathrm{w} / \mathrm{v})$, citric acid $(0.25 \%$ $\mathrm{w} / \mathrm{v}), \mathrm{CaCl}_{2}(1 \% \mathrm{w} / \mathrm{v})$ and glycerol $(1 \% \mathrm{v} / \mathrm{v})$.

The cubes were fully submerged into the solution for $1 \mathrm{~min}$ and drained by the use of nylon nets for 2 to $3 \mathrm{~min}$ to eliminate the excess of solution. The cubes were dried using a fan in a refrigerated environment for $30 \mathrm{~min}$. Finally, the samples were packed in non-recycled polyethylene terephthalete - PET packaging with a lid, with the same number of pieces per packaging, and stored at $4 \mathrm{C}$ for 12 days. The physical, physicochemical and microbiological tests were performed in triplicate on the day of processing the samples (day 0 ) and after 1, 3, 5, 7, 9 and 12 days of storage.

\section{Physical Analysis}

Weight Loss. The weight loss was obtained by taking the difference between the initial weight of the minimally processed peach and that obtained at the end of each storage time, according to the formula: $(\%)$ Weight loss $=[($ initial 
mass - final mass $) /($ initial mass $)] \times 100$. The results were expressed as percentage of weight loss.

\section{Texture Analysis}

The measurements of peach cube firmness were determined by using a texture analyzer Model TA-XT2 plus (Stable Micro Systems, Surrey, England). A cylindrical probe in the pre-test speed of $4 \mathrm{~mm} / \mathrm{s}$, post test of $8 \mathrm{~mm} / \mathrm{s}$, test of $2 \mathrm{~mm} / \mathrm{s}$ and penetration depth of $5 \mathrm{~mm}$ was used. The results were expressed in Newton $(\mathrm{N})$.

Color. The color analysis was evaluated by using a Minolta colorimeter, model Chroma Meter CR400. The parameters $L^{*}\left(0\right.$ [black] to 100 [white]), $a^{*}$ (green chromaticity [-60] to red $[+60]$ ) and $b^{\star}$ (blue chromaticity $[-60]$ to yellow $[+60]$ ) and Hue angle (showing the location of a color diagram, where the angle $0^{\circ}$ represents pure red, $90^{\circ}$ represents pure yellow, $180^{\circ}$ pure green and $270^{\circ}$ pure blue). A standard white calibration plate was used (Djioua et al. 2009).

pH. The $\mathrm{pH}$ was determined using the method described by AOAC (2000). $\mathrm{pH}$ was measured using a digital $\mathrm{pH}$ meter (Model PA 200, Marconi Instruments, Inc., Piracicaba, SP). A suspension of $20 \mathrm{~g}$ of sample in $100 \mathrm{ml}$ of distilled water was prepared, thus measuring the $\mathrm{pH}$ with the aid of a $\mathrm{pH}$ meter.

Total Soluble Solids. The content of total soluble solids was determined in a bench-type refractometer Abbé, with temperature correction to 20C. The results were expressed in ${ }^{\circ}$ Brix (AOAC 2000).

\section{Microbiological Analysis}

The microbiological tests were carried out to detect the presence of psychotrophic spp., and yeasts and molds, following the method described in APHA (2001).

\section{Statistical Analysis}

The physical and physicochemical evaluations were submitted to variance analysis and comparison of the mean was done by Tukey's test with a significance level of 5\%, using Statistica 7.0 software (StatSoft, Inc., Tulsa, OK).

\section{RESULTS AND DISCUSSION}

\section{Physical and Physicochemical Analyses}

Table 1 shows the values of mass loss of minimally processed peaches with different coatings, stored at $4 \pm 1 \mathrm{C}$ for 12 days.

There was an increase in the mass loss of minimally processed peaches during storage in all treatments. However, the loss was significantly lower in coated peaches than in the control (T1). This treatment presented the highest mass loss, $34.1 \%$ in the 12 days of storage. Treatment T4 presented the lowest loss $(7.60 \%)$, whereas treatment $\mathrm{T} 3$ presented the highest mass loss among the coated samples (10.87\%). According to Raybaudi-Massilia et al. (2007) and Villalobos-Carvajal et al. (2009), edible coatings can reduce mass loss because they help to decrease water loss from minimally processed products. However, in this work, tara gum presented the best results in relation of mass loss.

There are no reports of studies that show mass loss in minimally processed peaches, only using the whole fruit. Jacometti et al. (2003) evaluated mass loss of whole peaches coated with gelan gum stored at 10C for 16 days; however, they did not observe significant difference in mass loss of coated fruits with gelan gum and the uncoated control. Oliveira and Cereda (2003) showed that the mass loss of whole peaches stored at $27 \mathrm{C}$ during 12 days is dependent on the coating applied. Treatment with commercial wax and micro emulsion allowed less mass loss when compared to control treatment and with cassava starch. Maftoonazad et al. (2008) evaluated reduction of loss of moisture of

\begin{tabular}{lllll}
\hline & \multicolumn{4}{l}{ Treatments } \\
\cline { 2 - 5 } Days & T1 & \multicolumn{1}{l}{ T2 } & \multicolumn{1}{l}{ T4 } \\
\hline 0 & $0.0^{\mathrm{gA}}$ & $0.0^{\mathrm{gA}}$ & $0.0^{\mathrm{gA}}$ & $0.0^{\mathrm{gA}}$ \\
1 & $1.27 \pm 0.02^{\mathrm{fA}}$ & $0.73 \pm 0.01^{\mathrm{fC}}$ & $1.06 \pm 0.02^{\mathrm{fB}}$ & $0.83 \pm 0.01^{\mathrm{BB}}$ \\
3 & $2.22 \pm 0.01^{\mathrm{eC}}$ & $3.09 \pm 0.01^{\mathrm{AA}}$ & $2.89 \pm 0.01^{\mathrm{eB}}$ & $1.35 \pm 0.02^{\mathrm{eD}}$ \\
5 & $4.17 \pm 0.03^{\mathrm{dC}}$ & $4.69 \pm 0.02^{\mathrm{dB}}$ & $5.94 \pm 0.01^{\mathrm{dA}}$ & $2.16 \pm 0.01^{\mathrm{dD}}$ \\
7 & $8.95 \pm 0.01^{\mathrm{CA}}$ & $5.69 \pm 0.02^{\mathrm{CC}}$ & $6.53 \pm 0.01^{\mathrm{CB}}$ & $2.88 \pm 0.01^{\mathrm{CD}}$ \\
9 & $21.77 \pm 0.01^{\mathrm{bA}}$ & $6.81 \pm 0.01^{\mathrm{bC}}$ & $7.13 \pm 0.02^{\mathrm{bB}}$ & $4.09 \pm 0.02^{\mathrm{bD}}$ \\
12 & $34.1 \pm 0.03^{\mathrm{aA}}$ & $8.38 \pm 0.02^{\mathrm{aC}}$ & $10.87 \pm 0.03^{\mathrm{aB}}$ & $7.6 \pm 0.02^{\mathrm{aD}}$ \\
\hline
\end{tabular}

TABLE 1. MASS LOSS (\%) OF MINIMALLY PROCESSED PEACHES USING DIFFERENT COATINGS, STORED AT $4 \pm 1$ C FOR 12 DAYS

Means followed by the same letter in the column and capital letter in the row did not differ by Tukey's test $(P<0.05)$. (T1) control; (T2) alginate $2 \%$, ascorbic acid $1 \%$, citric acid $0.25 \%$, $\mathrm{CaCl}_{2} 1 \%$, glycerol $1 \%$; (T3) xanthan gum $0.5 \%$, ascorbic acid $1 \%$, citric acid $0.25 \%, \mathrm{CaCl}_{2} 1 \%$, glycerol $1 \%$; (T4) tara gum $0.5 \%$, ascorbic acid $1 \%$, citric acid $0.25 \%, \mathrm{CaCl}_{2} 1 \%$, glycerol $1 \%$. 
TABLE 2. FIRMNESS VALUES (N) OF MINIMALLY PROCESSED PEACHES USING DIFFERENT COATINGS, STORED AT $4 \pm 1 \mathrm{C}$ FOR 12 DAYS

\begin{tabular}{lllll}
\hline \multirow{4}{*}{ Days } & \multicolumn{4}{l}{ Treatments } \\
\cline { 2 - 5 } & $\mathrm{T} 1$ & $\mathrm{~T} 2$ & $\mathrm{~T}$ & $\mathrm{~T}$ \\
\hline 0 & $14.70 \pm 0.71^{\mathrm{eC}}$ & $14.90 \pm 0.12^{\mathrm{dC}}$ & $17.76 \pm 1.03^{\mathrm{bB}}$ & $20.13 \pm 0.92^{\mathrm{aA}}$ \\
1 & $14.71 \pm 0.68^{\mathrm{eC}}$ & $14.92 \pm 0.17^{\mathrm{cdC}}$ & $17.77 \pm 1.05^{\mathrm{bB}}$ & $20.13 \pm 0.86^{\mathrm{aA}}$ \\
3 & $15.92 \pm 0.21^{\mathrm{dC}}$ & $15.78 \pm 0.25^{\mathrm{bcC}}$ & $18.65 \pm 0.58^{\mathrm{abB}}$ & $20.87 \pm 0.91^{\mathrm{aA}}$ \\
5 & $17.28 \pm 0.17^{\mathrm{cC}}$ & $16.43 \pm 0.35^{\mathrm{abC}}$ & $19.09 \pm 0.71^{\mathrm{abB}}$ & $21.19 \pm 0.77^{\mathrm{aA}}$ \\
7 & $18.50 \pm 0.32^{\mathrm{bB}}$ & $16.72 \pm 0.22^{\mathrm{aC}}$ & $19.52 \pm 0.85^{\mathrm{abB}}$ & $21.43 \pm 0.88^{\mathrm{aA}}$ \\
9 & $18.75 \pm 0.16^{\mathrm{abC}}$ & $16.47 \pm 0.08^{\mathrm{abD}}$ & $19.81 \pm 0.46^{\mathrm{abB}}$ & $21.23 \pm 0.21^{\mathrm{aA}}$ \\
12 & $19.87 \pm 0.19^{\mathrm{aB}}$ & $16.04 \pm 0.11^{\mathrm{abcC}}$ & $20.75 \pm 0.69^{\mathrm{aA}}$ & $21.07 \pm 0.19^{\mathrm{aA}}$ \\
\hline
\end{tabular}

Means followed by the same letter in the column and capital letter in the row did not differ by Tukey's test $(P<0.05)$. (T1) control; (T2) alginate $2 \%$, ascorbic acid $1 \%$, citric acid $0.25 \%$, $\mathrm{CaCl}_{2} 1 \%$, glycerol $1 \%$; (T3) xanthan gum $0.5 \%$, ascorbic acid $1 \%$, citric acid $0.25 \%, \mathrm{CaCl}_{2} 1 \%$, glycerol $1 \%$; (T4) tara gum $0.5 \%$, ascorbic acid $1 \%$, citric acid $0.25 \%, \mathrm{CaCl}_{2} 1 \%$, glycerol $1 \%$. whole peaches by the use of coatings based on methyl cellulose and sodium alginate in 24 days of storage at 15C. After 12 days of storage, the mass loss in the uncoated control peaches was three times higher than the peaches coated with methyl cellulose and two times with sodium alginate.

Table 2 shows firmness values $(N)$ of minimally processed peaches using different coatings, stored at $4 \pm 1 \mathrm{C}$ for 12 days.

There was an increase of firmness in all treatments; however, in the treatment with tara gum (T4), the difference was not significant during the whole period of storage. The increase of firmness from the first to the last day of storage was $4.46 \%$. The control treatment showed higher increase in firmness when comparing the first and the last day of storage, reaching $26 \%$, followed by the treatment with xanthan, $14.4 \%$, and alginate $7.1 \%$. There was no connection between firmness increase and calcium chloride addition, since this increase was also observed in the control sample (T1), which did not receive calcium addition. However, there was a correlation between the values obtained in the mass loss with the increase in the firmness. This increase in firmness values may have been caused by water loss through evaporation and exudation, which promote drying of the surface tissues. According to Souza et al. (2005), this effect in minimally processed papaya is due to formation of a resistant superficial tissue due to higher moisture loss, making the pieces to become firmer during storage.

Chagas et al. (2008) evaluated firmness of minimally processed peaches treated with different concentrations of citric acid. According to their results, firmness was maintained in the first 9 days with a subsequent reduction. In the study carried out by Martins (2010), in which minimally processed peaches were treated with different concentrations of ascorbic acid and calcium chloride, there was maintenance of firmness in the samples treated with ascorbic acid and increase in the ones treated with calcium chloride in 12 days of storage at $3 \mathrm{C}$. When different packaging materials were evaluated by the authors, the maintenance of firmness occurred mainly with the use of polyethylene terephthalate packaging $(\mathrm{PET})$, in relation to polyvinylchloride and polyolefin.

In a study by Costa (2010),. the maintenance of firmness was observed in minimally processed peaches treated with ascorbic acid and sodium chloride and also in the control sample. In the other treatments (L-cysteine hydrochloride and calcium chloride; L-cysteine hydrochloride, ascorbic acid and calcium chloride), there was a firmness reduction tendency justified by the increase in the metabolic activity, enzymes and substrates decompartmentalization, which promote depolymerization of pectin. Oliveira and Cereda (2003) evaluated the firmness of whole peaches treated with different coatings including cassava starch, microemulsion based on cassava starch and commercial wax. In all treatments, a reduction of firmness values during storage was observed. These results agree with the ones obtained by Maftoonazad et al. (2008); however, according to them, the coated fruits showed a beneficial effect in firmness maintenance when compared with the control sample. Methyl cellulose was more efficient in retaining firmness than sodium alginate.

Table 3 shows values of lightness $\left(L^{\star}\right)$ of minimally processed peaches using different coatings, stored at $4 \pm 1 \mathrm{C}$ for 12 days.

There was a reduction in $L^{*}$ values in all treatments, suggesting browning of minimally processed peaches. The lowest reduction in $L^{\star}$ values was observed using coatings T4 $(6.42 \%)$ and T3 (10.40\%), while for the control treatment, the reduction in $L^{\star}$ values was $17.20 \%$ and in T2 it was $14.45 \%$.

The highest lightness loss in the control sample can be explained because the sample was not treated with the antioxidants ascorbic and citric acids. These are effective agents in the control of enzymatic browning, as they are capable of reducing quinones to phenols (Toralles et al. 2008). However, similar to this study, other works also show that 


\begin{tabular}{|c|c|c|c|c|}
\hline \multirow[b]{2}{*}{ Days } & \multicolumn{4}{|l|}{ Treatments } \\
\hline & $\mathrm{T} 1$ & $\mathrm{~T} 2$ & T3 & T4 \\
\hline 0 & $63.76 \pm 0.24^{\mathrm{ac}}$ & $67.04 \pm 0.16^{\mathrm{aB}}$ & $67.60 \pm 0.05^{\mathrm{aA}}$ & $67.80 \pm 0.27^{\mathrm{aA}}$ \\
\hline 1 & $62.05 \pm 0.97^{\mathrm{bB}}$ & $66.23 \pm 0.07^{\mathrm{abA}}$ & $66.44 \pm 0.14^{\mathrm{bA}}$ & $67.50 \pm 0.21^{\mathrm{aA}}$ \\
\hline 3 & $60.89 \pm 0.67^{c c}$ & $64.16 \pm 0.65^{\mathrm{bcB}}$ & $65.34 \pm 0.34^{\mathrm{CA}}$ & $65.36 \pm 0.16^{\mathrm{bA}}$ \\
\hline 5 & $60.72 \pm 0.11^{c c}$ & $62.68 \pm 0.31^{\mathrm{cdB}}$ & $64.96 \pm 0.14^{\mathrm{dA}}$ & $65.35 \pm 0.15^{\mathrm{bA}}$ \\
\hline 7 & $58.11 \pm 0.28^{\mathrm{dD}}$ & $60.9 \pm 0.21^{\mathrm{dec}}$ & $63.59 \pm 0.08^{\mathrm{eB}}$ & $64.71 \pm 0.27^{\mathrm{bcA}}$ \\
\hline 9 & $56.57 \pm 0.07^{\mathrm{eD}}$ & $59.72 \pm 0.19^{\mathrm{efc}}$ & $62.53 \pm 0.16^{\mathrm{eB}}$ & $64.18 \pm 0.52^{\mathrm{cdA}}$ \\
\hline 12 & $52.81 \pm 0.37^{f D}$ & $57.35 \pm 0.26^{f c}$ & $60.57 \pm 0.07^{\mathrm{fB}}$ & $63.45 \pm 0.18^{\mathrm{dA}}$ \\
\hline
\end{tabular}

TABLE 3. LIGHTNESS VALUES $\left(L^{*}\right)$ OF MINIMALLY PROCESSED PEACHES USING DIFFERENT COATINGS, STORED AT $4 \pm 1 \mathrm{C}$ FOR 12 DAYS

Means followed by the same letter in the column and capital letter in the line did not differ by Tukey's test $(P<0.05)$. (T1) control; (T2) alginate $2 \%$, ascorbic acid $1 \%$, citric acid $0.25 \%$, $\mathrm{CaCl}_{2} 1 \%$, glycerol $1 \%$; (T3) xanthan gum $0.5 \%$, ascorbic acid $1 \%$, citric acid $0.25 \%, \mathrm{CaCl}_{2} 1 \%$, glycerol $1 \%$; (T4) tara gum $0.5 \%$, ascorbic acid $1 \%$, citric acid $0.25 \%, \mathrm{CaCl}_{2} 1 \%$, glycerol $1 \%$.

even when using antioxidant agents, the color of minimally processed peaches is partially altered.

Chagas et al. (2008) observed a decrease in the lightness values $\left(L^{*}\right)$ during storage of minimally processed peaches treated with different concentrations of citric acid. A study by Martins (2010) also observed reduction in the lightness values in 12 days of storage of minimally processed peaches submitted to treatments with ascorbic acid and calcium chloride and different packaging materials. Yet at the end of the storage period, there was no significant difference between the control and the different treatments. Costa (2010) observed a decline in lightness values in samples of minimally processed peaches treated with ascorbic acid and calcium chloride; L-cysteine hydrochloride and calcium chloride; L-cysteine hydrochloride, ascorbic acid and calcium chloride. However, the lowest values of $L^{*}$ were observed in the control treatment.

Table 4 shows the values of $a^{\star}$ of minimally processed peaches using different coatings, stored at $4 \pm 1 \mathrm{C}$ for 12 days.

Values of $a^{*}$ in the different treatments oscillated during the period evaluated, tending to increase toward the end of the storage period. This increase indicates higher intensity of red color. The lowest increase in the values of $a^{*}$ was observed using T4 (36.9\%) and T3 (38.5\%) coatings. In the control treatment, there was an increase of $48.2 \%$. T2 resulted in an increase of $43.8 \%$. Different results were found by Chagas et al. (2008). According to their results, values of $a^{*}$ did not differ significantly during the 9 days of storage and neither among minimally processed peaches treated with citric acid (1\% and 2\%).

Table 5 shows values of $b^{*}$ of minimally processed peaches using different coatings, stored at $4 \pm 1 \mathrm{C}$ for 12 days. There were also fluctuations in the values of $b^{*}$ during storage; however, at the end of the storage, there was a decrease tendency, indicating increase of intensity of blue color. As for T2, the value of $b^{\star}$ from the last day of storage was higher than the value at day 0 , tending to a yellowish color stronger than the initial one. The increase in the values of $a^{\star}$, as well as reduction in the values of $b^{*}$ may indicate an oxidative browning.

The lowest reduction in the values of $b^{\star}$ was observed using coatings T3 $(9.00 \%), \mathrm{T} 4(11.06 \%)$ and control sample $(16 \%)$. Treatment T2 showed an increase in the value of $b^{*}$ of $2.20 \%$ in the last day of storage. Similar behavior was observed by Chagas et al. (2008), as the values of $b^{*}$ decreased in 9 days of storage of minimally processed peaches treated with citric acid.

\begin{tabular}{lrrrr}
\hline \multirow{4}{*}{ Days } & \multicolumn{4}{l}{ Treatments } \\
\cline { 2 - 5 } T1 & \multicolumn{1}{l}{ T2 } & \multicolumn{1}{c}{ T3 } \\
\hline 0 & $8.01 \pm 0.92^{\mathrm{eAB}}$ & $7.02 \pm 0.09^{\mathrm{eB}}$ & $8.64 \pm 0.21^{\mathrm{fA}}$ & $7.52 \pm 0.07^{\mathrm{AAB}}$ \\
1 & $11.89 \pm 0.31^{\mathrm{cdA}}$ & $7.93 \pm 0.12^{\mathrm{deD}}$ & $9.44 \pm 0.06^{\mathrm{eB}}$ & $8.54 \pm 0.13^{\mathrm{dC}}$ \\
3 & $12.87 \pm 0.44^{\mathrm{bCA}}$ & $9.18 \pm 0.35^{\mathrm{cdB}}$ & $12.29 \pm 0.06^{\mathrm{cdA}}$ & $7.21 \pm 0.40^{\mathrm{eC}}$ \\
5 & $11.64 \pm 0.08^{\mathrm{dB}}$ & $9.85 \pm 0.29^{\mathrm{cC}}$ & $13.27 \pm 0.18^{\mathrm{bA}}$ & $11.42 \pm 0.11^{\mathrm{aB}}$ \\
7 & $13.81 \pm 0.15^{\mathrm{bA}}$ & $8.74 \pm 0.08^{\mathrm{cdD}}$ & $12.14 \pm 0.28^{\mathrm{dB}}$ & $10.85 \pm 0.17^{\mathrm{bC}}$ \\
9 & $13.70 \pm 0.12^{\mathrm{bA}}$ & $12.42 \pm 0.04^{\mathrm{bB}}$ & $12.63 \pm 0.21^{\mathrm{cB}}$ & $10.23 \pm 0.06^{\mathrm{cC}}$ \\
12 & $15.49 \pm 0.17^{\mathrm{aAB}}$ & $16.02 \pm 0.06^{\mathrm{aA}}$ & $14.05 \pm 0.05^{\mathrm{aB}}$ & $11.93 \pm 0.16^{\mathrm{aC}}$ \\
\hline
\end{tabular}

Means followed by the same letter in the column and capital letter in the line did not differ by Tukey's test $(P<0.05)$. (T1) control; (T2) alginate $2 \%$, ascorbic acid $1 \%$, citric acid $0.25 \%$, $\mathrm{CaCl}_{2} 1 \%$, glycerol $1 \%$; (T3) xanthan gum $0.5 \%$, ascorbic acid $1 \%$, citric acid $0.25 \%, \mathrm{CaCl}_{2} 1 \%$, glycerol $1 \%$; (T4) tara gum $0.5 \%$, ascorbic acid $1 \%$, citric acid $0.25 \%, \mathrm{CaCl}_{2} 1 \%$, glycerol $1 \%$.
TABLE 4. VALUES OF $a^{*}$ OF MINIMALLY PROCESSED PEACHES USING DIFFERENT COATINGS, STORED AT $4 \pm 1 C$ FOR 12 DAYS 
TABLE 5. VALUES OF $b^{*}$ OF MINIMALLY PROCESSED PEACHES USING DIFFERENT COATINGS, STORED AT $4 \pm 1 C$ FOR 12 DAYS

\begin{tabular}{|c|c|c|c|c|}
\hline \multirow[b]{2}{*}{ Days } & \multicolumn{4}{|l|}{ Treatments } \\
\hline & $\mathrm{T} 1$ & $\mathrm{~T} 2$ & T3 & T4 \\
\hline 0 & $58.45 \pm 0.38^{\mathrm{aA}}$ & $43.97 \pm 0.21^{\mathrm{eC}}$ & $51.02 \pm 0.24^{\mathrm{bB}}$ & $51.01 \pm 0.06^{\mathrm{bB}}$ \\
\hline 1 & $52.25 \pm 1.35^{\mathrm{bB}}$ & $48.35 \pm 0.17^{\mathrm{aD}}$ & $50.3 \pm 0.13^{c c}$ & $54.20 \pm 0.18^{\mathrm{aA}}$ \\
\hline 3 & $50.37 \pm 0.93^{\mathrm{cB}}$ & $47.01 \pm 0.16^{b c}$ & $52.98 \pm 0.31^{\mathrm{aA}}$ & $45.85 \pm 0.23^{d C}$ \\
\hline 5 & $50.02 \pm 0.07^{\mathrm{CB}}$ & $46.02 \pm 0.20^{c c}$ & $51.47 \pm 0.22^{\mathrm{bA}}$ & $46.48 \pm 0.19^{c c}$ \\
\hline 7 & $47.70 \pm 0.26^{\mathrm{dB}}$ & $42.85 \pm 0.12^{\mathrm{fD}}$ & $49.82 \pm 0.21^{\mathrm{cA}}$ & $45.11 \pm 0.26^{\mathrm{ec}}$ \\
\hline 9 & $45.70 \pm 0.13^{\mathrm{eB}}$ & $45.72 \pm 0.16^{\mathrm{cB}}$ & $46.58 \pm 0.25^{\mathrm{dA}}$ & $45.13 \pm 0.21^{\mathrm{ec}}$ \\
\hline 12 & $43.71 \pm 0.21^{\mathrm{fc}}$ & $44.96 \pm 0.13^{\mathrm{dB}}$ & $45.79 \pm 0.32^{\mathrm{eA}}$ & $45.37 \pm 0.19^{\mathrm{de} A B}$ \\
\hline
\end{tabular}

Means followed by the same letter in the column and capital letter in the line did not differ by Tukey's test $(P<0.05)$. (T1) control; (T2) alginate $2 \%$, ascorbic acid $1 \%$, citric acid $0.25 \%$, $\mathrm{CaCl}_{2} 1 \%$, glycerol $1 \%$; (T3) xanthan gum $0.5 \%$, ascorbic acid $1 \%$, citric acid $0.25 \%, \mathrm{CaCl}_{2} 1 \%$, glycerol $1 \%$; (T4) tara gum $0.5 \%$, ascorbic acid $1 \%$, citric acid $0.25 \%, \mathrm{CaCl}_{2} 1 \%$, glycerol $1 \%$.
Table 6 shows values of Hue Angle $\left(\mathrm{H}^{*}\right)$ of minimally processed peaches using different coatings stored at $4 \pm 1 \mathrm{C}$ for 12 days.

There was a tendency to decrease the values of Hue Angle in all treatments applied to minimally processed peaches. This indicates that the tone changed from yellow to a reddish color.

The lowest percentage reduction was obtained in the treatment with tara gum (T4 $-7.8 \%$ ), followed by xanthan gum (T3 - 9.3\%) and sodium alginate (T2 - 13\%). Uncoated treatment $\mathrm{T} 1$ showed reduction in the value of Hue Angle since the beginning of the experiment until the last day of storage, presenting the highest percentage reduction (15.6\%) in the value of Hue Angle.

Similar behavior was observed by Martins (2010) with minimally processed peaches submitted to treatments with ascorbic acid and calcium chloride, as well as with different packaging materials. Values of Angle Hue decreased during storage from yellow-green tone to bright yellow, regardless of the treatment applied.

In the study by Costa (2010), a fluctuation in the values of Angle Hue during storage was observed. As for lightness, the lowest values were observed in the control treatment. On the other hand, the highest values (angles close to $90^{\circ}$ ) were observed in the treatment with ascorbic and citric acid, which represents a more intense yellow.

Table 7 shows $\mathrm{pH}$ values of minimally processed peaches using different coatings, stored at $4 \pm 1 \mathrm{C}$ for 12 days.

The $\mathrm{pH}$ of the control sample (T1) was maintained during storage, and at time zero it was significantly higher than the other treatments, as it had no addition of citric and ascorbic acids. There was a $\mathrm{pH}$ increase in the other treatments from the third and fifth day of storage. However, there was no significant difference among treatments at the end of storage. Maintenance or even increasing of $\mathrm{pH}$ values is expected when calcium chloride is added, as this compound is a salt chlorinate of basic nature providing buffer capacity (Andrade 2006).

Different results have been reported in literature. Chagas et al. (2008) showed that in minimally processed peaches treated with different concentrations of citric acid the $\mathrm{pH}$ was maintained throughout the storage period. At the end of storage there was no difference between the treatments with citric acid. Studies performed by Togrul and Arslan (2004) and Maftoonazad et al. (2008) with coating of whole peaches showed similar results to the ones obtained in the present work as there was increase in the $\mathrm{pH}$ during storage.
TABLE 6. VALUES OF HUE ANGLE $\left(H^{*}\right)$ OF MINIMALLY PROCESSED PEACHES USING DIFFERENT COATINGS STORED AT $4 \pm 1 \mathrm{C}$ FOR 12 DAYS

\begin{tabular}{|c|c|c|c|c|}
\hline \multirow[b]{2}{*}{ Days } & \multicolumn{4}{|l|}{ Treatments } \\
\hline & $\mathrm{T} 1$ & $\mathrm{~T} 2$ & T3 & $\mathrm{T} 4$ \\
\hline 0 & $82.2 \pm 0.16^{\mathrm{aA}}$ & $80.93 \pm 0.11^{\mathrm{ac}}$ & $80.39 \pm 0.27^{\mathrm{aD}}$ & $81.61 \pm 0.07^{\mathrm{aB}}$ \\
\hline 1 & $77.18 \pm 0.51^{b c}$ & $80.73 \pm 0.07^{\mathrm{aA}}$ & $79.37 \pm 0.04^{\mathrm{bB}}$ & $81.08 \pm 0.16^{\mathrm{aA}}$ \\
\hline 3 & $75.64 \pm 0.78^{\mathrm{CD}}$ & $78.92 \pm 0.11^{\mathrm{bB}}$ & $76.94 \pm 0.37^{c c}$ & $81.06 \pm 0.33^{\mathrm{aA}}$ \\
\hline 5 & $75.49 \pm 0.13^{c c}$ & $78.01 \pm 0.19^{c A}$ & $75.54 \pm 0.15^{\mathrm{dec}}$ & $76.2 \pm 0.15^{\mathrm{CB}}$ \\
\hline 7 & $73.95 \pm 0.11^{d c}$ & $78.55 \pm 0.03^{\mathrm{bcA}}$ & $76.32 \pm 0.20^{\mathrm{cdB}}$ & $76.47 \pm 0.23^{\mathrm{CB}}$ \\
\hline 9 & $73.38 \pm 0.11^{d c}$ & $74.92 \pm 0.46^{\mathrm{dB}}$ & $74.82 \pm 0.17^{\mathrm{eB}}$ & $77.23 \pm 0.16^{\mathrm{bA}}$ \\
\hline 12 & $69.41 \pm 0.16^{\mathrm{eD}}$ & $70.39 \pm 0.12^{\mathrm{ec}}$ & $72.94 \pm 0.09^{\mathrm{fB}}$ & $75.26 \pm 0.18^{\mathrm{dA}}$ \\
\hline
\end{tabular}

Means followed by the same letter in the column and capital letter in the line did not differ by Tukey's test $(P<0.05)$. (T1) control; (T2) alginate $2 \%$, ascorbic acid $1 \%$, citric acid $0.25 \%$, $\mathrm{CaCl}_{2} 1 \%$, glycerol $1 \%$; (T3) xanthan gum $0.5 \%$, ascorbic acid $1 \%$, citric acid $0.25 \%, \mathrm{CaCl}_{2} 1 \%$, glycerol $1 \%$; (T4) tara gum $0.5 \%$, ascorbic acid $1 \%$, citric acid $0.25 \%, \mathrm{CaCl}_{2} 1 \%$, glycerol $1 \%$. 


\begin{tabular}{cllll}
\hline \multirow{4}{*}{ Days } & \multicolumn{4}{l}{ Treatments } \\
\cline { 2 - 5 } & $\mathrm{T} 1$ & $\mathrm{~T} 2$ & $\mathrm{~T} 3$ & $\mathrm{~T}$ \\
\hline 0 & $4.01 \pm 0.02^{\mathrm{Aa}}$ & $3.79 \pm 0.03^{\mathrm{cB}}$ & $3.78 \pm 0.05^{\mathrm{Bbc}}$ & $3.70 \pm 0.03^{\mathrm{bC}}$ \\
1 & $4.01 \pm 0.01^{\mathrm{aA}}$ & $3.80 \pm 0.02^{\mathrm{bcB}}$ & $3.78 \pm 0.02^{\mathrm{bB}}$ & $3.71 \pm 0.01^{\mathrm{bC}}$ \\
3 & $4.09 \pm 0.11^{\mathrm{aA}}$ & $3.86 \pm 0.08^{\mathrm{bcB}}$ & $3.98 \pm 0.03^{\mathrm{aAB}}$ & $3.95 \pm 0.04^{\mathrm{aAB}}$ \\
5 & $4.11 \pm 0.05^{\mathrm{aA}}$ & $4.00 \pm 0.07^{\mathrm{abA}}$ & $4.10 \pm 0.09^{\mathrm{aA}}$ & $4.04 \pm 0.07^{\mathrm{aA}}$ \\
7 & $4.17 \pm 0.09^{\mathrm{aA}}$ & $4.13 \pm 0.10^{\mathrm{aAB}}$ & $4.05 \pm 0.05^{\mathrm{aAB}}$ & $3.96 \pm 0.02^{\mathrm{aB}}$ \\
9 & $4.24 \pm 0.03^{\mathrm{aA}}$ & $4.20 \pm 0.09^{\mathrm{aA}}$ & $4.02 \pm 0.02^{\mathrm{aB}}$ & $3.95 \pm 0.03^{\mathrm{aB}}$ \\
12 & $4.02 \pm 0.25^{\mathrm{aA}}$ & $4.14 \pm 0.08^{\mathrm{aA}}$ & $4.01 \pm 0.01^{\mathrm{aA}}$ & $3.92 \pm 0.09^{\mathrm{aA}}$ \\
\hline
\end{tabular}

TABLE 7. PH VALUES OF MINIMALLY PROCESSED PEACHES USING DIFFERENT COATINGS STORED AT $4 \pm 1$ C FOR 12 DAYS

Means followed by the same letter in the column and capital letter in the line did not differ by Tukey's test $(P<0.05)$. (T1) control; (T2) alginate $2 \%$, ascorbic acid $1 \%$, citric acid $0.25 \%$, $\mathrm{CaCl}_{2} 1 \%$, glycerol $1 \%$; (T3) xanthan gum $0.5 \%$, ascorbic acid $1 \%$, citric acid $0.25 \%, \mathrm{CaCl}_{2} 1 \%$, glycerol $1 \%$; (T4) tara gum $0.5 \%$, ascorbic acid $1 \%$, citric acid $0.25 \%, \mathrm{CaCl}_{2} 1 \%$, glycerol $1 \%$.

Table 8 shows values of content of total soluble solids ( ${ }^{\circ}$ Brix) of minimally processed peaches using different coatings, stored at $4 \pm 1 \mathrm{C}$ for 12 days.

The content of soluble solids was influenced by the treatment applied to minimally processed peaches. In treatments $\mathrm{T} 1$ and T2, there was an increase in soluble solids from the first and the last day of storage, but in treatments T3 and $\mathrm{T} 4$, there was a reduction in soluble solids.

The increase in the content of total soluble solids observed in control sample (T1) and in the treatment with alginate (T2) can be the result of sugars accumulation, which is concentrated by loss of moisture, a process that occurs during fruit ripening even though in small scale. This ripening was restricted in the treatments with xanthan gum (T3) and tara gum (T4). The reduction of total soluble solids content observed in T3 and T4 can be attributed to the fact that the immersion of fruits in filmogenic solutions may have leached the total soluble solids of the fruit (Trigo 2010). Tendency of increase in the values of $\mathrm{pH}$ of minimally processed peaches was observed by Costa (2010). In their study, both the control sample and the ones treated with ascorbic acid and calcium chloride; L-cysteine hydrochloride and calcium chloride; L-cysteine hydrochloride, ascorbic acid and calcium chloride, showed this tendency.
Martins (2010) observed that soluble solids content ( ${ }^{\circ}$ Brix) remained constant during the storage of minimally processed peaches, with no significant difference of the values among different treatments with ascorbic acid and calcium chloride. Nevertheless, when different packages were evaluated, different results were observed. The highest values of soluble solids were found in products from treatments with packaging PD 955 and PD 900 (polyolefin); according to the authors, this behavior is a result of biochemical reactions resulting from the ripening. PET, PVC $11 \mu \mathrm{m}$ and PVC $14 \mu \mathrm{m}$ packages provided a higher restraint of the ripening of products during storage. Chagas et al. (2008) also did not observe differences in the content of soluble solids when minimally processed peaches were treated with $1 \%$ and $2 \%$ citric acid and stored for 9 days at 5 C.

\section{Microbiological Analyses}

Figure 1 shows growth curves of psychotrophic microorganisms in minimally processed peaches with and without coating, stored for 12 days.

In the analysis of psychotrophic species, the initial count for all treatments was below $2 \mathrm{log} \mathrm{cfu} / \mathrm{g}$, and treatment 4

\begin{tabular}{clrrr}
\hline & \multicolumn{4}{l}{ Treatments } \\
\cline { 2 - 5 } Days & T1 & \multicolumn{1}{l}{ T2 } & \multicolumn{1}{l}{ T3 } \\
\hline 0 & $12.67 \pm 0.07^{\mathrm{bCA}}$ & $10.3 \pm 0.10^{\mathrm{eC}}$ & $10.83 \pm 0.02^{\mathrm{aB}}$ & $12.6 \pm 0.02^{\mathrm{aA}}$ \\
1 & $12.60 \pm 0.08^{\mathrm{cA}}$ & $10.4 \pm 0.09^{\mathrm{deC}}$ & $10.90 \pm 0.05^{\mathrm{aB}}$ & $12.63 \pm 0.05^{\mathrm{aA}}$ \\
3 & $11.90 \pm 0.05^{\mathrm{dA}}$ & $10.6 \pm 0.02^{\mathrm{dC}}$ & $10.90 \pm 0.07^{\mathrm{aC}}$ & $11.30 \pm 0.11^{\mathrm{bCB}}$ \\
5 & $11.97 \pm 0.09^{\mathrm{dA}}$ & $11.0 \pm 0.01^{\mathrm{CB}}$ & $10.90 \pm 0.05^{\mathrm{aB}}$ & $10.9 \pm 0.13^{\mathrm{cB}}$ \\
7 & $12.60 \pm 0.10^{\mathrm{cA}}$ & $12.0 \pm 0.01^{\mathrm{aB}}$ & $10.90 \pm 0.01^{\mathrm{aD}}$ & $11.10 \pm 0.10^{\mathrm{bCC}}$ \\
9 & $12.90 \pm 0.11^{\mathrm{abA}}$ & $11.73 \pm 0.09^{\mathrm{abB}}$ & $10.3 \pm 0.12^{\mathrm{bC}}$ & $11.30 \pm 0.30^{\mathrm{bCB}}$ \\
12 & $13.10 \pm 0.2^{\mathrm{aA}}$ & $11.63 \pm 0.07^{\mathrm{bB}}$ & $9.4 \pm 0.17^{\mathrm{cC}}$ & $11.60 \pm 0.30^{\mathrm{bB}}$ \\
\hline
\end{tabular}

Means followed by the same letter in the column and capital letter in the line did not differ by Tukey's test $(P<0.05)$. (T1) control; (T2) alginate $2 \%$, ascorbic acid $1 \%$, citric acid $0.25 \%$, $\mathrm{CaCl}_{2} 1 \%$, glycerol $1 \%$; (T3) xanthan gum $0.5 \%$, ascorbic acid $1 \%$, citric acid $0.25 \%, \mathrm{CaCl}_{2} 1 \%$, glycerol $1 \%$; (T4) tara gum $0.5 \%$, ascorbic acid $1 \%$, citric acid $0.25 \%, \mathrm{CaCl}_{2} 1 \%$, glycerol $1 \%$.
TABLE 8. CONTENT OF TOTAL SOLUBLE SOLIDS ('BRIX) OF MINIMALLY PROCESSED PEACHES USING DIFFERENT COATINGS STORED AT $4 \pm 1 C$ FOR 12 DAYS 


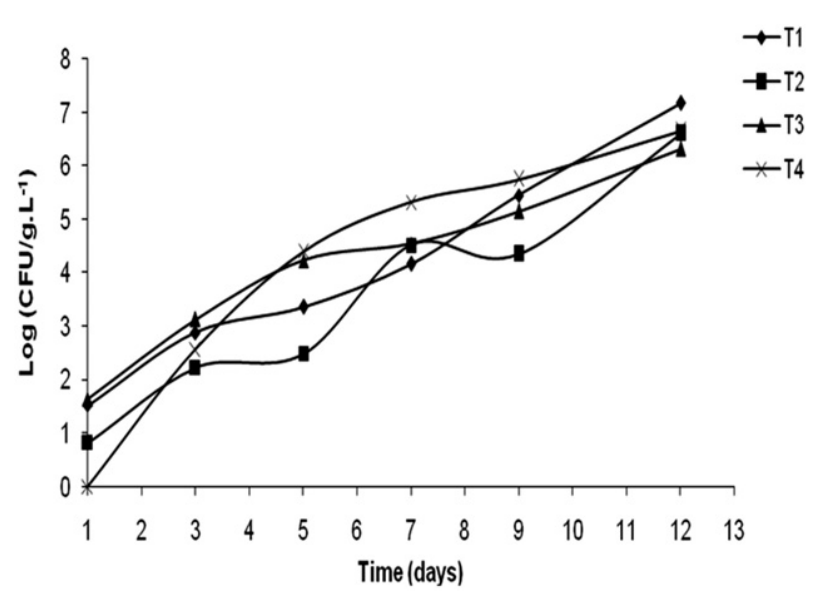

FIG. 1. COUNTING OF PSYCHOTROPIC MICROORGANISMS IN MINIMALLY PROCESSED PEACHES USING DIFFERENT COATINGS

(T1) control; (T2) alginate $2 \%$, ascorbic acid $1 \%$, citric acid $0.25 \%$, $\mathrm{CaCl} 21 \%$, glycerol $1 \%$; (T3) xanthan gum $0.5 \%$, ascorbic acid $1 \%$, citric acid $0.25 \%, \mathrm{CaCl} 21 \%$, glycerol $1 \%$; (T4) tara gum $0.5 \%$, ascorbic acid $1 \%$, citric acid $0.25 \%, \mathrm{CaCl} 21 \%$, glycerol $1 \%$.

(with tara gum) was the one that had the lowest initial growth for these microorganisms. Throughout the storage period, there was an increase in the count and a similar behavior in relation to psychotrophic growth. However, growth of these microorganisms in the control sample (T1) was higher than the growth with coatings in the 12 days of storage, reaching $7.17 \log \mathrm{cfu} / \mathrm{g}$. However, in treatments with coatings, the final count was $6.6 \mathrm{log} \mathrm{cfu} / \mathrm{g}$ for treatment 2, $6.31 \mathrm{log} \mathrm{cfu} / \mathrm{g}$ for treatment 3 and $6.65 \mathrm{log} \mathrm{cfu} / \mathrm{g}$ for treatment 4 .

Figure 2 shows growth curves of molds and yeasts for all treatments applied to minimally processed peaches.

As it can be seen in Fig. 2, treatments T3 and T4 had similar behavior for the growth of molds and yeasts and these treatments presented lower growth for these microorganisms, when compared with the other treatments. At the end of the storage period, these treatments reached $4.0 \mathrm{log}$ $\mathrm{cfu} / \mathrm{g}$ and $3.9 \mathrm{log} \mathrm{cfu} / \mathrm{g}$, respectively. The highest count of molds and yeasts occurred in the control sample (5.49 log $\mathrm{cfu} / \mathrm{g})$ followed by treatment T2 (5.12 $\log \mathrm{cfu} / \mathrm{g})$. There are no reports in literature about microbiological evaluation of psychotrophic microorganisms, molds and yeasts in minimally processed peaches.

According to Kester and Fennema (1986), the use of coatings with low gas permeability, as it is the case of polysaccharides, reduces the access to oxygen, minimizing microbiological alterations. Similar behavior to the one observed in this study was verified by Jacometti et al. (2003) in whole peaches coated with gelan gum and stored at $10 \mathrm{C}$. After 2 weeks of storage, coated peaches presented lower counts of psychotrophic microorganisms than uncoated fruits; however, there was no difference in mold and yeast counts between coated samples and control.

Olivas et al. (2007) in their studies with minimally processed apples coated with alginate and stored at $4 \mathrm{C}$, found low levels of psychotrophs $\left(10^{1} \mathrm{cfu} / \mathrm{g}\right)$ and molds and yeasts $\left(\left\langle 10^{1} \log \mathrm{cfu} / \mathrm{g}\right)\right.$ during the whole period of storage. These counts were lower than the ones found in the present study in treatment 2 with alginate in which $10^{6} \mathrm{cfu} / \mathrm{g}$ were obtained for psychotrophs and $10^{5} \mathrm{cfu} / \mathrm{g}$ for molds and yeasts.

It has been recognized that foods with microbial counts above $10^{6} \mathrm{cfu} / \mathrm{g}$ are unsuitable for human consumption, due to loss of nutritional value, sensorial alterations and contamination risks (Vitti et al. 2004). Therefore, all samples analyzed became unsuitable for consumption after 9 days of storage, due to psychotrophic microorganisms. Regarding mold and yeast counts, in 12 days, all samples were still below the limit.

\section{CONCLUSION}

It can be concluded that the different coatings used in this work were effective in the preservation of minimally processed peaches, when compared with the control sample. Regarding the coatings evaluated, treatment with tara gum associated to citric and ascorbic acids and to calcium chloride showed the best results, especially when compared to alginate treatment, which is the main polysaccharide currently used as edible coating. Tara gum caused reduction in mass loss, maintaining firmness, less color alteration and lower growth of yeasts and molds. Thus, this gum has

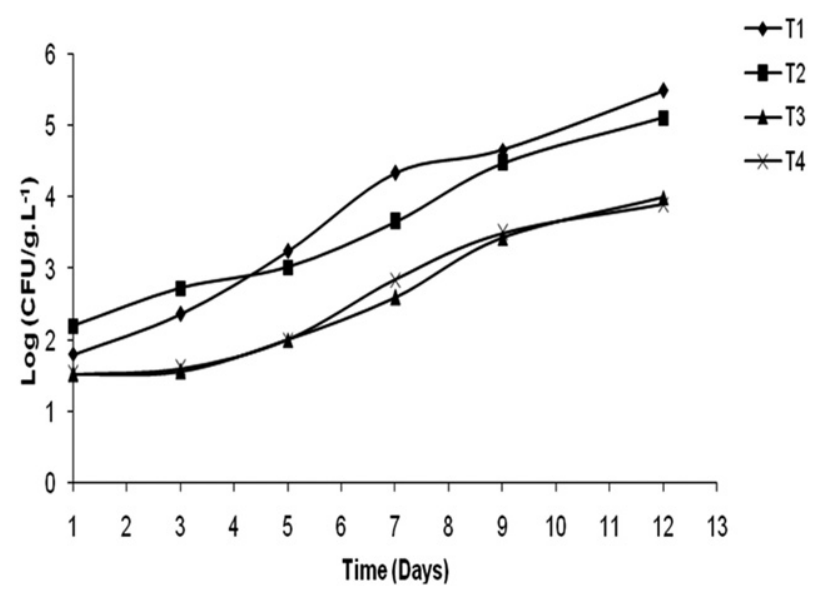

FIG. 2. GROWTH OF MOLDS AND YEASTS IN MINIMALLY PROCESSED PEACHES WITH DIFFERENT COATINGS

(T1) control; (T2) alginate $2 \%$, ascorbic acid $1 \%$, citric acid $0.25 \%$, $\mathrm{CaCl} 21 \%$, glycerol $1 \%$; (T3) xanthan gum $0.5 \%$, ascorbic acid $1 \%$, citric acid $0.25 \%, \mathrm{CaCl} 21 \%$, glycerol $1 \%$; (T4) tara gum $0.5 \%$, ascorbic acid $1 \%$, citric acid $0.25 \%, \mathrm{CaCl} 21 \%$, glycerol $1 \%$. 
potential for the application as coating in minimally processed peaches from Granada cultivar.

\section{REFERENCES}

ANDRADE, S.R.R. 2006. Processing Minimum of the mom (Carica papaya L.): Effects of additives Chemicals and modified atmosphere in the product quality. Thesis (Master in Food Science and Techonology): School of Agriculture "Luiz de Queiroz", University of São Paulo, Brazil. 180p.

AOAC. 2000. Official Methods of Analysis. Association of Official Analytical Chemists, 16th Ed., AOAC International, Arlington, VA.

APHA - AMERICAN PUBLIC HEALTH ASSOCIATION. 2001. Compendium of Methods for the Microbiological Examination of Foods, 676 p, APHA International, Washington, DC.

ÇAYKARA, T., DEMIRCI, S., EROGLU, M.S. and GÜVEN, O. 2005. Poly(ethylene oxide) and its blends with sodium alginate. Polymer 46, 10750-10757.

CHAGAS, P.C., SHIRAHIGE, F.H., SILVA, P.P.M., SPOTO, M.H.F., CHAGAS, E.A. and PIO, R. 2008. Avaliação da qualidade de pêssegos "regis" minimamente processados. B. CEPPA, Curitiba 26(2), 179-186, jul./dez.

COSTA, A.C. 2010. Study of the Conservation of peach [Prunus persica (L.) Batsch] minimally processed. Thesis (Agroindustrial Science and Technology), Federal University of Pelotas. Brazil. 79p.

DELLA CRUZ, R. 2004. Understanding and evaluating fresh-cut produce. Fresh-cut, Washington, 12, n.9, 7-8.

DJIOUA, T., CHARLES, F., LOPEZ-LAURI, F., FILGUEIRAS, H., COUDRET, A., FREIRE, M., Jr, DUCAMP-COLLIN, M.N. and SALLANON, H. 2009. Improving the storage of minimally processed mangoes (Mangifera indica L.) by hot water treatments. Postharvest Biol. Technol. 52, 221-226.

FSANZ. 2006. Tara gum as a food additive. Food Standars. New Zealand, Austrália.

GARCÍA-OCHOA, F., SANTOS, V.E., CASAS, J.A. and GÓMEZ, E. 2000. Xanthan gum: Production, recovery and properties. Biotechnol. Adv. 18, 549-579.

GIL, M.I., TOMAS-BARBERAN, F.A., HESS-PIERCE, B. and KADER, A.A. 2002. Antioxidant capacities, phenolic compounds, carotenoids, and vitamin C contents of nectarine, peach, and plum cultivars from California. J. Agric. Food Chem. 50, 4976-4982.

JACOMETTI, G.A., MENEGHEL, R.F.A. and YAMASHITA, F. 2003. Use of edible coating in peaches. Ciênc. Tecnol. Aliment. 23, 95-100.

KESTER, J.J. and FENNEMA, O.R. 1986. Edible films and coatings: A review. Food Technol. 40(12), 47-59. Chicago.

KROCHTA, J.M. and MULDER-JOHNSTON, C. 1997. Edible and biodegradable polymer films: Challenges and opportunities. Food Technol. 51(2), 61-74.

MAFTOONAZAD, N., RAMASWAMY, H.S. and MARCOTTE, M. 2008. Shelf-life extension of peaches through sodium alginate and methyl cellulose edible coatings. Int. J. Food Sci. Technol. 43, 951-957.

MARTINS, R.N. 2010. Minimal processing of peaches Aurora-1': Stages of maturation, packaging, storage temperatures and natural additives. Thesis. School of Agricultural Sciences and Veterinary). Estadual Paulista University. 145p.

OLIVAS, G.I., MATTINSON, D.S. and BARBOSA-CÁNOVAS, G.V. 2007. Alginaté coatings for preservation of minimally processed "Gala" apples. Postharvest Biol. Technol. 45, 89-96.

OLIVEIRA, M.A. and CEREDA, M.P. 2003. Pós-colheita de pêssegos (Prunus pérsica L. Bastsch) revestidos com filmes a base de amido como alternativa à cera comercial. Ciênc. Tecnol. Aliment. 23, 28-33.

RAYBAUDI-MASSILIA, R.M., MOSQUEDA-MELGAR, J., SOBRINO-LÓPEZ, A., SOLIVA-FORTUNY, R. and MARTÍN-BELLOSO, O. 2007. Shelf-life extension of fresh-cut "Fuji" apples at different ripeness stages using natural substances. Postharvest Biol. Technol. 45, 265-275.

ROJAS-GRAÜ, M.A., RAYBAUDI-MASSILIA, R.M., SOLIVA-FORTUNY, R.C., AVENA-BUSTILLOS, R.J., MCHUGH, T.H. and MARTÍN-BELLOSO, O. 2007. Apple puree-alginaté edible coating as carrier of antimicrobial agents to prolong shelf-life of fresh-cut apples. Postharvest Biol. Technol. 45, 254-264.

SCORZA, R. 2005. Peach and Apricot. Processing Fruits: Science and Technology, 2nd Ed., pp. 481-483, CRC Press, New York, NY.

SEBRAE. 2012. Agência Sebrae de notícias RS. http://www. agenciasebrae.com.br (accessed February 20th, 2012).

SITTIKIJYOTHIN, W., TORRES, D. and GONÇALVES, M.P. 2005. Modelling the rheological behaviour of galactomannan aqueous solutions. Carbohydr. Polym. 59, 339-350.

SITTIKIJYOTHIN, W., SAMPAIO, P. and GONÇALVES, M.P. 2007. Heat-induced gelation of b-lactoglobulin at varying $\mathrm{pH}$ : Effect of tara gum on the rheological and structural properties of the gels. Food Hydrocol 21, 1046-1055. SOUZA, B.S., DURIGAN, J.F., DONADON, J.R. and LIMA, M.A. 2005. Quality and physiological behavior of fresh cut "Formosa" papaya. Braz. J. Food Technol. 8, 243-247.

SUTHERLAND, I.W. 1993. Xanthan, pp. 363-388, Chapman \& Hall, London, U.K.

TOGRUL, H. and ARSLAN, N. 2004. Extending shelf-life of peach and pear by using CMC from sugar beet pulp cellulose as a hydrophilic polymer in emulsions. Food Hydrocol 18, 215-226.

TORALLES, R.P., VENDRUSCOLO, J.L., VENDRUSCOLO, C.T., DEL PINO, F.A.B. and ANTUNES, P.L. 2008. Determinação das constantes cinéticas de degradação do ácido ascórbico em purê de pêssego: efeito da temperatura e concentração. Ciênc. Tecnol. Aliment. 28(1), 18-23, jan.-mar.

TRIGO, J.M. 2010. Quality of papaya "Formosa" minimally processed using edible coatings. Thesis (Master in Food Science and Techonology): School of Agriculture "Luiz de Queiroz", University of São Paulo, Brazil. 105p. 
VERSARI, A., CASTELARI, M., PARPINELLO, G.P., RIPONI, C. and GALASSI, S. 2002. Characterization of peach juices obtained from cultivars Redhaven, Suncrest and Maria Marta grown in Italy. Food Chem. 76, 181-185. Barking.

VILLALOBOS-CARVAJAL, R., HERNÁNDEZ-MUÑOZ, P., ALBORS, A. and CHIRALT, A. 2009. Barrier and optical properties of edible hydroxypropyl methylcellulose coatings containing surfactants applied to fresh cut carrot slices. Food Hydrocol 23, 526-535.
VITTI, M.C.D., KLUGE, R.A., GALLO, C.R., SCHIAVINATO, M.A., MORETTI, C.L. and JACOMINO, A.P. 2004.

Physiological and microbiological aspects of fresh cut beet roots. Pesqui. Agropec. Bras. 39, 1027-1032.

XUEWU, Z., XIN, L., DEXIANG, G., WEI, Z., TONG, X. and YONGHONG, M. 1996. Rheological models for xanthan gum. J. Food Eng. 27, 203-209. 